\title{
Atrophoderma of Pasini and Pierini a variant of morphea?
}

\section{Vasile Sturza', Anca E. Chiriac², Iulia Emet', Vladislav Gogu¹, Mircea Betiu¹}

I"Nicolae Testemitanu" State University of Medicine and Pharmacy, Dermatology Hospital SDMC, Dermatology

Department, Chisinau, Republic of Moldova, ${ }^{2}$ University of Medicine and Pharmacy "Grigore T. Popa", Faculty of Medicine, PhD Student, Iasi, Romania

Corresponding author: Anca E. Chiriac MD, E-mail: chiriancut@yahoo.com

Sir,

Pasini described the skin disease in 1923 [1], and, a few years later, in 1936 Pierini and Vivoli reported the same disorder [2]; for many years it has been known as atrophoderma of Pasini and Pierini (APP). In 1958 the name APP was replaced by other terms, such as atrophic scleroderma d'emblee and dyschromic and atrophic variation of scleroderma [3], suggesting that APP could be a variant of scleroderma. In 1995 a new classification of scleroderma has been published and APP was considered a form of localized plaque morphea $[4,5]$. Furthermore, Buechner and Rufli simply stated that APP should be considered as an "abortive, primarily atrophic variant of morphea" [6] and, in the view of Amano et al, APP and morphea should be regarded as "similar nosologic entity" [7].

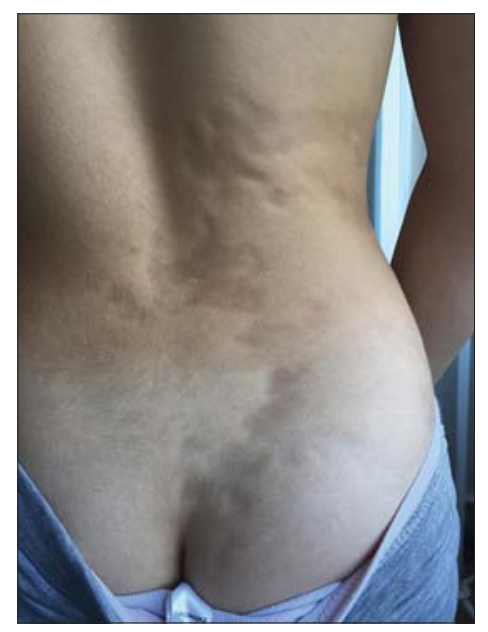

Figure 1: Atrophic lesions like "footprints in the snow".

\begin{tabular}{|c|c|c|}
\hline & $\begin{array}{l}\text { Atrophoderma Pasini } \\
\text { Pierini }\end{array}$ & Morphea \\
\hline Other names & $\begin{array}{l}\text { Atrophic scleroderma } \\
\text { d'emblee dyschromic } \\
\text { and atrophic variation of } \\
\text { scleroderma }\end{array}$ & Localized scleroderma \\
\hline Incidence & $\begin{array}{l}\text { Unknown (less than } 100 \text { cases } \\
\text { published) }\end{array}$ & $0.4-2.7 / 100000[8]$ \\
\hline Age of onset & $\begin{array}{l}\text { Early onset } \\
\text { Adolescents-young adults }\end{array}$ & $\begin{array}{l}\text { Late onset } \\
\text { third-fifth decades }\end{array}$ \\
\hline $\begin{array}{l}\text { Gender } \\
\text { predominance }\end{array}$ & Female predominance 6:1 [9] & $\begin{array}{l}\text { Female predominance } \\
\text { unpublished ratio }\end{array}$ \\
\hline $\begin{array}{l}\text { Clinical } \\
\text { features }\end{array}$ & $\begin{array}{l}\text { "Inverted plaque" } \\
\text { depressed lesions } \\
\text { "footprints in the snow" (Fig. 1) } \\
\text { lack of inflammation } \\
\text { absence of induration of the } \\
\text { skin }\end{array}$ & $\begin{array}{l}\text { Ivory, indurated plaque } \\
\text { with lilac ring (Fig. 2) } \\
\text { Inflammation, erythema, } \\
\text { edema }\end{array}$ \\
\hline $\begin{array}{l}\text { Distribution } \\
\text { of the lesions }\end{array}$ & $\begin{array}{l}\text { most frequently on the trunk } \\
\text { chest, abdomen, limbs }\end{array}$ & no \\
\hline $\begin{array}{l}\text { Color of the } \\
\text { lesions }\end{array}$ & $\begin{array}{l}\text { commonly hyperpigmented } \\
\text { hypopigmented or skin colored }\end{array}$ & $\begin{array}{l}\text { Ivory plaque with lilac } \\
\text { ring } \\
\text { bruise-like pink }\end{array}$ \\
\hline Symptoms & $\begin{array}{l}\text { Asymptomatic } \\
\text { extremely rare pruritus, } \\
\text { paresthesia }\end{array}$ & Asymptomatic \\
\hline $\begin{array}{l}\text { Number of } \\
\text { lesions }\end{array}$ & multiple, disseminated & $\begin{array}{l}\text { single or multiple } \\
\text { plaques }\end{array}$ \\
\hline $\begin{array}{l}\text { Size of the } \\
\text { lesions }\end{array}$ & few $\mathrm{mm}$ to several $\mathrm{cm}$ & few to several $\mathrm{cm}$ \\
\hline Histology & $\begin{array}{l}\text { Reduced thickness of the } \\
\text { dermis } \\
\text { Atrophy, sclerosis, } \\
\text { hyalinization or fragmentation } \\
\text { of the collagen bundles } \\
\text { normal sweat and sebaceous } \\
\text { glands }\end{array}$ & $\begin{array}{l}\text { Diffuse sclerosis of the } \\
\text { dermis } \\
\text { Horizontalisation } \\
\text { and thickening of } \\
\text { collagen bundles in the } \\
\text { hipodermis } \\
\text { Inflammatory infiltrate in } \\
\text { the 'lilac ring' area } \\
\text { atrophic sweat and } \\
\text { sebaceous glands }\end{array}$ \\
\hline
\end{tabular}

During all these years pro and cons have been published concerning the relation between APP and morphea.

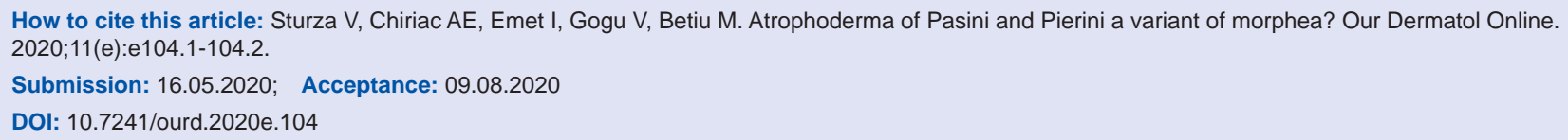




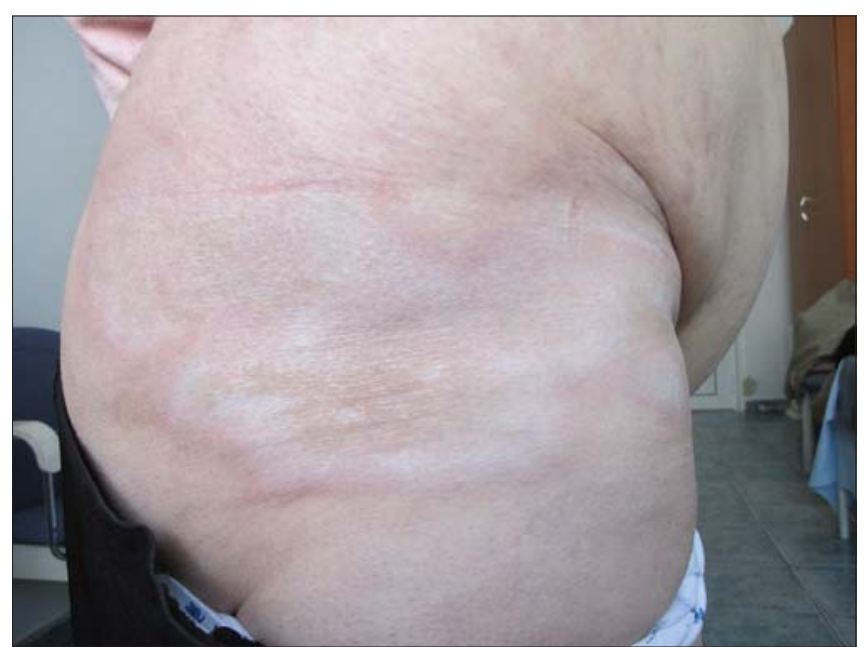

Figure 2: Ivory, indurated plaque with lilac ring.

\section{REFERENCES}

1. Pasini A. Atrofodermia idioatica progressiva. G Ital Dermatol. 1923;58:785.
2. Pierini L, Vivoli D. Atrofodermia progressiva (Pasini) G Ital Dermatol. 1936;77:403-9.

3. Canizares O, Sachs PM, Jaimovich L, Torres VM. Idiopathic atrophoderma of Pasini and Pierini. AMA Arch Derm. 1958;77:42-58.

4. Peterson LS, Nelson AM, Su WP. Classification of morphea (localized scleroderma). Mayo Clinic Proc. 1995;70:1068-76.

5. Bachaspatimayum R, Bhattacharjee N, Das P. Atrophoderma of Pasini and Pierini: An unusual presentation. Our Dermatol Online. 2019;10:355-7.

6. Buechner SA, Rufli T. Atrophoderma of Pasini and Pierini. Clinical and histopathologic findings and antibodies to Borrelia burgdorferi in thirty-four patients. J Am Acad Dermatol. 1994;30:441-6.

7. Amano H, Nagai Y, Ishikawa O. Multiple morphea coexistent with atrophoderma of Pasini-Pierini (APP): APP could be abortive morphea. J Eur Acad Dermatol Venereol. 2007;21:1254-6.

8. Fett N, Erth VP. Update on morphea: part I. Epidemiology, clinical presentation and pathogenesis. J Am Acad Dermatol. 2011;64:217-29.

9. Litaiem N, Idoudi S. Atrophoderma of Pasini and Pierini. In: StatPearls. Treasure Island (FL): StatPearls Publishing; 2020.

Copyright by Sturza Vasile, et al. This is an open access article distributed under the terms of the Creative Commons Attribution License, which permits unrestricted use, distribution, and reproduction in any medium, provided the original author and source are credited.

Source of Support: Nil, Conflict of Interest: None declared. 